\title{
The Effect of Country of Origin Image on Purchase Intention: A Case Study on Bahir Dar University Instructors
}

\section{Aschalew Degoma ${ }^{1 *}$ and Elias Shetemam ${ }^{2}$}

${ }^{1}$ Assistant professor and senior lecturer in marketing management department, Bahir Dar University, Bahir Dar, Ethiopia

${ }^{2}$ Lecturer in marketing management department, Bahir Dar University, Bahir Dar, Ethiopia

\begin{abstract}
Purpose: The purpose of this study is to examine the effects of country-of-origin image on the purchase intention of domestic and foreign products in Ethiopia in order to pin point the key determinant factors based on which managerial recommendations are forwarded.

Design/methodology/approach: to accomplish the objectives, a set of questionnaire were developed and dispatched to the respondents as self administered survey. 200 questionnaires were distributed to the randomly selected Bahir Dar University instructors of which 189 filled questionnaires qualified for analysis using structural equation modeling with AMOS 18 version software.

Findings: It was determined that country of origin image plays a significant role in predicting purchase intentions towards domestically produced goods and products from European country.

The results indicated that the effect of country of origin image is significant in the case of domestic and foreign products in Ethiopia.
\end{abstract}

Keywords: Country-of-origin image; Purchase intention; Effect of country of origin

\section{Introduction}

The globalization of markets presents considerable opportunities and challenges for both domestic and international markets [1]. The relaxation of trade policies has provided consumers with more foreign product choices than ever before. Consequently, their attitudes toward products originating from foreign countries have been of interest to international business and consumer behavior researchers for decades [2]. Previous studies on the Country-of-Origin Effect (COE), most of which have been conducted in developed countries, have found that consumers have a general preference for domestic over foreign merchandise, particularly when they lack information about the product [3-7]

Like brands, countries should also have equity associated with them. Consumers tend to embrace certain ideas and stereotypes of foreign countries as producers of goods and services and then use these ideas to evaluate the qualities of these products [8]. Accordingly, marketers have shown a growing interest in understanding how country associated with the products influence the consumers' quality judgments and purchasing decisions [9].

Country of origin effect can be defined as any influence that the country of manufacture has on a consumer's positive or negative perception of a product [10]. With increasing availability of foreign goods in most national markets, the country of origin cue has become more important as consumers often evaluate imported goods differently than they do competing domestic products [3]. Nowadays, more companies are competing on the global market, and these companies manufacture their products worldwide and the location where they manufacture the products might affect the perception of the consumer on the quality of the product based on the country where the product is produced.

Past country of origin studies have demonstrated the existence of negative biases towards products made in foreign countries [11-13].
This is particularly evident in developed countries where domestic products tend to be evaluated more favorably than foreign made products [14]

Conversely, in the case of developing countries, national products tend to be evaluated less favorably than imported goods from developed countries $[15,16]$.

As such, willingness to buy domestic/foreign products is influenced by country of origin and quality judgment [1]. Thus, increased globalization has attracted interest in Country-of-Origin (COO) research and how they affect decision-making [17]. Both domestic and foreign firms need to understand consumers' perceptions and evaluations of foreign products against domestic ones.

Although, a lot of research were undertaken on the influence of $\mathrm{COO}$ in industrialized countries yet studies on its effect in developing countries have remained relatively low [18]. According to them the transitional economies are very promising for its growth potential and are distinctive from developed nations. Even the results found in previous studies conducted on developed nations may not be applicable for developing nations. Moreover, no study has been carried out on the influence of country of origin image on purchase intension in the context of Ethiopia, (to the best of the researchers' knowledge), one of the developing countries in the world with varied ethnic and cultural diversities.

*Corresponding author: Aschalew Degoma, Assistant professor and senior lecturer in marketing management department, Bahir Dar University, Bahir Dar Ethiopia, Tel: +251 -582- 2022 37; E-mail: aschalewde@yahoo.com

Received August 12, 2013; Accepted January 27, 2014; Published February 05 2014

Citation: Degoma A, Shetemam E (2014) The Effect of Country of Origin Image on Purchase Intention: A Case Study on Bahir Dar University Instructors. J Account Mark 3: 109. doi: 10.4172/2168-9601.1000109

Copyright: (c) 2014 Degoma A, et al. This is an open-access article distributed under the terms of the Creative Commons Attribution License, which permits unrestricted use, distribution, and reproduction in any medium, provided the original author and source are credited. 


\section{Objective of study}

The major objective of this study is to examine the relationships among the set of exogenous, Country of Origin Image (COI), and endogenous variables, Perceived Quality (PQ) and Purchase Intention (PI), for both of the domestic and foreign products using structural equation modeling in order to come with new marketing insights for Ethiopian marketers.

Specifically the study tried:

$\checkmark$ To test whether COI matters on PQ and PI of domestic and foreign products.

$\checkmark$ To test the impact of COI on PI of domestic and foreign products.

$\checkmark$ To examine the direct and indirect impact of COI on PI of domestic and foreign products.

$\checkmark \quad$ To assess the mediating role of PQ between COI and PI.

\section{Literature Review}

\section{The country of origin}

According to Kabadayi [19], the impact of COO on buyers' intention, assessment and perception has been the most studied topic in marketing, business and consumer behavior field for past few decades. A lot of researchers have attempted to find effects of COO on product evaluations, attitudes toward the product, purchase intention and purchase choice. Lants and Loeb [20] demonstrated that impact of COO is similar to brand, price and quality but it can be stronger.

$\mathrm{COO}$ assists as a cue using which customers evaluate a product's quality, performance and other attributes [21]. COO effect is an important determinant of consumer biasness [22]. As suggested by Peterson and Jolibert [23] consumers' perception toward a product varies with its specific origin. Consumers take $\mathrm{COO}$ as an extrinsic cue which is a predictor of quality for goods and services. Consumers create brand images for products and similarly they also form country images for specific countries. Through the country image they develop a brand image of a country which constitutes stereotypical beliefs of consumers [24].

Many consumers utilize country-of-origin stereotypes to appraise products for example, "Japanese electronics are reliable", "German cars are excellent", "Italian pizza are superb". Many consumers believe that a "Made in" label means a product is "superior" or "inferior" depending on their perception of the country [25].

Several studies have extensively documented that country of origin influences product evaluations. In general, evaluations of a country associated with a product leads to a corresponding favorable and unfavorable evaluation of a product [26].

$\mathrm{COO}$ is very important in evaluating foreign products principally from two main perspectives: quality [27] and purchase value [28].

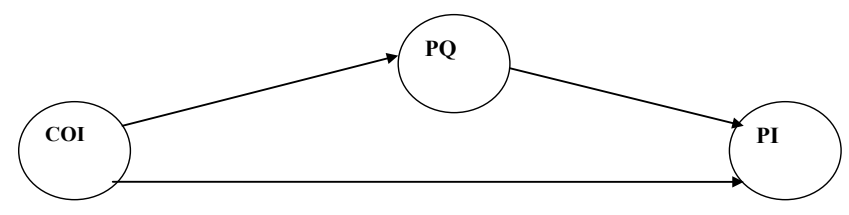

Figure 1: Framework of the Study.
One of the first concepts of the country-of-origin phenomenon was that of Nagashima [29] country image perception. He defined the image that consumers associate with a given country-of-origin as "the picture, the reputation, the stereotype that consumers attach to products of a specific country. This image is created by such variables as representative products, national characteristics, economic and political background, history, and traditions". Others view this country image as reflecting consumers' general perceptions about the quality of products made in a particular country and the nature of people from that country [30]. COO effect is concerned with how consumers perceive products sourced from a particular country [31]. Extant literature indicated that $\mathrm{COO}$ influence can be traced to product assessment and decision making processes as it affect consumers' prediction of likelihood of specific features of products manufactured in a certain country [32]. A number of studies have indicated consumers' bias favor of products from developed nations such as USA, European countries and Japan. This usually associated with high levels of economic and technological development [31] which translate to high quality and better performance of products.

\section{Conceptual model and hypotheses development of the study}

The path diagram model of the study depicted in Figure 1 portrays the relation between Country of Origin, Perceived Quality and Purchase intention variables in which Perceived quality and Purchase intention included in the study as a mediating and ultimate dependent variables respectively.

Pappu, Quester and Cooksey [33] suggest the positive or negative image a country has in consumers mind will affect the purchasing decision. Hui and Zhou [34] agree that COO directly influences purchase intentions. While, Cervino et al. [35] suggests that $\mathrm{COO}$ indirectly influence purchase intentions via other variables (product evaluation, brand image, brand equity and perceived value). Among various dependent variables product quality evaluations and purchase intensions appear to be more popular [36]. COO image has also a direct effect on the perception about product quality [37].

Cordell [38] explains $\mathrm{COO}$ as an important cue in the theory of decision making process. Elliot and Cameron [39] also believe COO to have negative or positive influence on consumer's decision making process. Verlegh and Steenkamp [22] stress that the impact of COO is noteworthy. They also reported that the effect of COO is substantial in product evaluation, but the author does not completely agree that it affects the final purchasing behavior and it can be affected by additional factors, like price.

All of the concepts have been widely recognized in the literature. The study was intended to examine the effects of country of origin image on Ethiopian consumers purchase behavior for both of the domestic and foreign products.

For both domestic and foreign countries, the following four alternative hypotheses have been formulated:

H1a: Domestic country-of-origin image has positive influence on perceived quality of domestic products.

H1b: Domestic country-of-origin image has positive and direct influence on purchase intention of domestic products.

H2a: Foreign country-of-origin image has positive influence on perceived quality of foreign products.

H2b: Foreign country-of-origin image has positive and direct influence on purchase intention of foreign products. 


\begin{tabular}{|c|c|c|c|}
$\begin{array}{c}\text { Model Goodness } \\
\text { Fitting }\end{array}$ & $\begin{array}{c}\text { Recommended } \\
\text { Value }\end{array}$ & $\begin{array}{c}\text { Value for Domestic } \\
\text { Products Model }\end{array}$ & $\begin{array}{c}\text { Value For } \\
\text { Foreign } \\
\text { Products Model }\end{array}$ \\
\hline $\begin{array}{c}\text { GFI (Goodness of Fit } \\
\text { Index) }\end{array}$ & $>0.9$ & 1.00 & 1.00 \\
\hline $\begin{array}{c}\text { RMR (Root Mean } \\
\text { Square Residual) }\end{array}$ & $<0.08$ & 0.00 & 0.00 \\
\hline NFI (Normed Fit Index) & $>0.9$ & 1.00 & 1.00 \\
\hline CFI (Comparative Fit \\
Index)
\end{tabular}

Table 1: Goodness Fitting for SemModel.

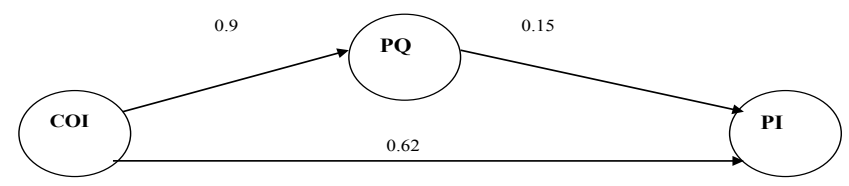

Figure 2: Structural equation model result of domestic country.

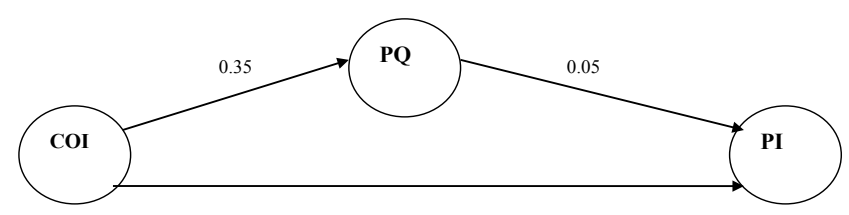

Figure 3: Structural equation model result of foreign country.

\section{Methodology}

\section{Questionnaire design}

All measures of the constructs of this study employed multiple-item scales that have been tested and used in previous studies and they were modified with great care in this study to reflect the characteristics of Ethiopian consumers. The modification is made specifically with regard to contexts and wordings.

COO Image: The scales of country-of-origin image are measured on eight stamens modified from Martin and Eroglu [40].

Perceived quality: The four dimensions were proposed to measure Perceived quality of products was adopted and consists of six items that are slightly modified to the characteristics of the country.

Purchase intention: purchase intention, the ultimate dependent variable of this study, was measured by two items, such as "I would like to purchase this product" and "I would recommend others to purchase this product". [41].

Sampling technique and sample size determination: the sampling procedure used for this study was a simple random sampling and the sample size was determined using the following formula.

$$
n=P(1-P) \frac{(Z \alpha)^{2}}{E}
$$

Where: $\mathrm{n}=$ sample size,

$\mathrm{P}=$ proportion, when it is not known a conservative value of $\mathrm{P}=$ 0.5 is assumed

$$
\alpha=\text { significance level (0.05) }
$$
take 0.5

$\mathrm{E}=$ margin of error and will have value $(0.04-0.06)$ usually or

\section{Data collection}

Self-administered questionnaires were used to collect the data from the instructors of Bahir Dar University. To maximize sample representativeness of instructors, the sampling frame was obtained from human resource management data base of Bahir Dar University, and was organized and coded with numeric number ranging from 11200. Finally using EXCEL the determined sample size (189) of this study was then selected randomly. Approximately 200 surveys were distributed to these instructors and 190 usable completed surveys were collected. And thus only 189 questionnaires were used in the analysis, providing a usable response rate of $94 \%$. And a $100 \%$ targeted sample size.

Data analysis: Structural Equation Modeling (SEM) with Amos 18 software was used for the data analysis. SEM is a comprehensive statistical approach for testing hypotheses about relations between observed and latent variables. It combines features of factor analysis and multiple regressions for studying both the measurement and the structural properties of theoretical models. SEM is formally defined by two sets of linear equations called the inner model and the outer model. The inner model specifies the relationships between unobserved or latent variables, and the outer model specifies the relationships between latent variables and their associated observed or manifest variables. SEM methodology can account for independent variable errors and model multiple relationships simultaneously, which results in more powerful tests of mean differences.

\section{Results and Findings}

\section{The model goodness fitting test}

The SEM model used to verify the hypotheses for domestic products and foreign products separately. The overall fit of the proposed model was perfect for both domestic and foreign countries (e.g. $\mathrm{RMR}=0.0$, $\mathrm{CFI}=1.00, \mathrm{GFI}=1.00$, and $\mathrm{IFI}=1.00$ ). Table 1 shows the common fit indices, recommended values and analytical results for total measurement model.

Given the satisfactory fit of the model, the estimated path coefficients of the structural model were then examined for both countries (domestic and foreign) to evaluate the proposed hypotheses. The following Figures 2 and 3 represents the standardized path coefficients of domestic and foreign countries respectively. All hypotheses were strongly supported. The fit statistics value of path weight between the constructs of perceived quality and purchase intention are positive 0.15 $(\mathrm{p}<0.05)$ for domestic products and $0.05(\mathrm{p}<0.05)$ for foreign products However, the positive coefficient of perceived quality on purchase intention for both countries is not significant.

The path coefficients of the country-of-origin image on perceived quality are $0.90(\mathrm{p}<0.001)$ for domestic products and $0.35(\mathrm{p}<0.001))$ for foreign products indicating the country-of-origin image positively affect the perceived quality no matter from which country. H1a and $\mathrm{H} 2 \mathrm{a}$ are supported. The path coefficients of the country-of-origin image on purchase intention is $0.29(\mathrm{p}<0.001)$ for foreign products, and 0.62 $(\mathrm{p}<0.001))$ for domestic products. $\mathrm{H} 2 \mathrm{~b}$ and $\mathrm{H} 1 \mathrm{~b}$ are also supported.

\section{The total Path Coefficients (direct + Indirect) of both countries for the proposed model}

Using the standardized path coefficients between constructs, the direct effect and the indirect effect of each construct on the purchase of foreign and local products can be calculated. The total summery of the 


\begin{tabular}{|c|c|c|c|c|c|c|}
\hline \multirow{2}{*}{} & \multicolumn{2}{|c|}{ DIRECT } & \multicolumn{2}{c|}{ INDIRECT } & \multicolumn{2}{c|}{ TOTAL } \\
\cline { 2 - 7 } & $\mathrm{PQ}$ & $\mathrm{PI}$ & $\mathrm{PQ}$ & $\mathrm{PI}$ & $\mathrm{PQ}$ & $\mathrm{PI}$ \\
\hline $\mathrm{COO}$ & 0.35 & 0.29 & & 0.18 & 0.346 & 0.304 \\
\hline $\mathrm{PQ}$ & 0.15 & & & & 0.15 & \\
\hline
\end{tabular}

Source: SEM data results

Table 2: Direct Effect, Indirect Effect and Total Effect of each construct on Foreign Purchase Intention.

\begin{tabular}{|c|c|c|c|c|c|c|}
\hline \multirow{2}{*}{} & \multicolumn{2}{|c|}{ DIRECT } & \multicolumn{2}{c|}{ INDIRECT } & \multicolumn{2}{c|}{ TOTAL } \\
\cline { 2 - 7 } & $\mathrm{PQ}$ & $\mathrm{PI}$ & $\mathrm{PQ}$ & $\mathrm{PI}$ & $\mathrm{PQ}$ & $\mathrm{PI}$ \\
\hline $\mathrm{COO}$ & 0.90 & 0.62 & & 0.14 & 0.90 & 0.76 \\
\hline $\mathrm{PQ}$ & 0.15 & & & & 0.15 & \\
\hline
\end{tabular}

\section{Source: SEM data results}

Table 3:The Direct Effect, Indirect Effect and Total Effect of each construct on Purchase intention of domestic products

standardized direct and indirect effect of each construct on purchase intention of foreign and domestic country shown separately in Tables 2 and 3 respectively.

The above table result indicates that the total indirect effect of $\mathrm{COO}$ on PI is positive and quite small whereas the direct effect is large and positive. The total effect is then the sum of direct and indirect impact $(0.29+0.18=0.304)$. That means the total extent impact of country of origin image has on purchase intention of foreign product is 0.304 . And to identify the role of mediating variable between the constructs, also it can be seen from the above results of regression analysis that the coefficient for country of origin $\rightarrow$ purchase intention has been reduced from 0.29 to 0.18 when perceived quality is added to the regression, and the total direct and indirect effect of domestic $\mathrm{COO}$ on domestic purchase intention is positive. Therefore the total effect is computed by summing the direct $(0.62)$ and indirect effect $(0.14)$.accordingly the total effect of domestic $\mathrm{COO}$ on domestic purchase intention is 0.62 $+0.14=0.76$. Table 3 also shows us the results of regression analysis that the coefficient for country of origin $\rightarrow$ purchase intention has been decreased from 0.62 to 0.14 when perceived quality is added to the regression, which indicates that perceived quality playing a mediating effect role in these relationships as prior observed in standardized path coefficient of foreign models also.

As per the recommendation of $\mathrm{Li}$ and Yan [42], mediation analysis has been proved, therefore, it can be inferred that perceived quality has mediating effect in the formation of the relationships between country of origin and purchase intention.

\section{Discussion and Conclusions}

The effects of country of origin image and perceived quality on domestic and foreign purchase intention were investigated in this research.

With Amos software, the study used SEM method to integrate the measurements and hypothesized causal paths into a simultaneous assessment. As SEM method has potential advantages over linear regression models, this study used SEM to analyze many stages of independent and dependent variables. The results of the two models for domestic and foreign products demonstrate the overall impact of country-of-origin on perceived quality and purchase intention.

The effect of country of origin is more important on perceived quality than on purchase intention.

The impact of domestic and foreign country-of-origin image on both perceived quality and purchase intention of Ethiopian consumers had been positive and significant, implying that the country-of-origin image affects positively the purchasing decisions and the judgments of perceived quality of domestic and foreign products. The results are consistent with prior study [42] which suppose that country-of-origin image has positive influence on purchase decision and judgments of perceived quality of both domestic and foreign products.

With regard to the construct of perceived quality, there was positive but insignificant impact of perceived quality on purchase intention for both countries. This result is consistent with prior studies of [43]. However, it is inconsistent with the study of Dae and Joon [44], Tsiotsou [45], Richardson et al. [46] and Hoch and Banerji [47] which indicates that perceived quality has positive and significant impact on purchase decision.

This is because of that purchase intentions do not only represent a tradeoff between consumer needs and product features, but also incorporate several external influences, of which budget constraints are the most important. Specially, consumers may perceive a product to be of high quality, and like it very much, but they may simply not be able to afford it, Judgments regarding perceived quality and purchase intentions sometimes can be formed independent of each other. However, there is conceptual support for the notion that perceived quality is a key component of purchase intention. They found that the overall purchase intention or attitude toward a product was affected by perceived quality, but also by convenience, fun and beauty. Thus, the intention concept is broader than the quality construct, encompassing more and different factors.

\section{Managerial implications}

The contribution of this study is to integrate the concepts of consumer's attitude towards the country, and examine the impact of country-of-origin on purchasing decisions for both domestic and foreign products. From a managerial perspective, this study provides insights regarding country-related factors that drive behavioral intentions and which, therefore, need to be considered when developing international marketing strategies. Marketers who seek to promote a "buy domestic" theme should reinforce positive associations of the home country and, in particular, target people via their feelings of national attachment.

The second managerial implication is to help the domestic and foreign enterprises in Ethiopia to adapt the consumer's attitude toward the country and make appropriate marketing campaigns. For example, marketing managers should pay attention to link country-of- origin image with product quality to increase consumer purchase behavior.

In general, it is important for marketers to emphasize on country of origin and product quality factors in marketing their products even in the local Ethiopian market.

\section{Limitation of the study and directions for future researcher}

Limitation of this study includes the lack of category specific investigation. While some researchers have demonstrated that $\mathrm{COO}$ affects consumer attitudes regardless of the product category [48] others have asserted that COO effects tend to vary by product category $[9,49]$. Hence, future examinations of consumer choice alternatives should investigate the relative effects of these mechanisms based on product category and include information about the specific COO of foreign alternatives.

Besides, Analysis of the hypotheses was based on a data set of 189 samples. Therefore, more researches could be conducted with larger set of samples. 
Citation: Degoma A, Shetemam E (2014) The Effect of Country of Origin Image on Purchase Intention: A Case Study on Bahir Dar University Instructors. J Account Mark 3: 109. doi: 10.4172/2168-9601.1000109

Page 5 of 5

Other variables such as brand name, price, income, and consumer involvement should also be controlled in the study, as they may affect the consumers' perceptions of product quality and willingness to buy. Direction of further research is to conduct research in other countries for comparison and to increase the generalizability of the study.

\section{References}

1. Klein JG, Ettenson R, Morris M (1998) The animosity model of foreign product purchase: an empirical test in the People's Republic of China. J Marketing 62 89-100.

2. Cheng Lu Wang, Zhen Xiong Chen (2004) Consumer ethnocentrism and willingness to buy domestic products in a developing country setting: testing moderating effects, Journal of Consumer Marketing, 21: 391-400.

3. Bilkey WJ, Nes E (1982) Country of origin effect on product evaluations, Journa of International Business Studies, 13: 89-99.

4. Damanpour F (1993) Temporal shifts of developed country- images: a 20 year view in Papadopulos, N. and Heslop, L.A. (Eds), Product-Country Images, pp. $357-78$

5. Elliott GR, Camoron RC (1994) Consumer perception of product quality and the country-of-origin effect, Journal of International Marketing, 2: 49-62.

6. Wall M and Heslop LA (1986) Consumer attitudes toward Canadian-made versus imported product. Journal of the Academy Marketing Science 14: 27-36.

7. Maheswaran D, Chen CY (2006) Nation Equity: Incidental Emotions in Countryof-Origin Effects. J Consum Res 33: 370-376.

8. Wall M and Heslop LA (1989) Consumer attitudes towards the quality of domestic and imported apparel and footwear. Journal of Consumer Studies and Home Economics 13: 337-358.

9. Balabanis G, Diamantopoulos A (2004) Domestic Country Bias, Country-of Origin Effectsand Consumer Ethnocentrism: A Multidimensional Unfolding Approach, Journal of the Academy of Marketing Science, 32: 80-95.

10. Cateora PR, Graham JL (1999) International Marketing. (13th Edition), Irwin McGraw-Hill.

11. Bannister JP, Saunders JA (1978) UK consumers attitudes towards imports: The measurement of national stereotype image, European Journal of Marketing 12: $562-570$

12. Kaynak E, Cavusgil S (1983) Consumer Attitudes towards Products ofForeign Origin: Do they vary across Product Classes? International Journal of Advertising 2: 147-157.

13. Litvin SW (1998) Tourism: The world's peace industry? Journal of Trave Research 37: 63-66.

14. Mowen JC (1995) Consumer Behavior, 4th edition, Englewood CWs, New Jersey: Prentice-Hall Inc.

15. Abbas NA (2010) Ethnocentrism and Attitude of Jordanian Consumer towards Foreign Products: Using Structural Equation Modelling, AMOS-SEM. (Published PhD thesis), University of Utara. Malaysia.

16. Hamin C, Elliott G (2006) A less-developed country perspective of consume ethnocentrism \&country of origin effects: Indonesian evidence, Asia Pacific Journal of Marketing and Logistics 18: 79-92.

17. Papadopoulos $\mathrm{N}$ and Heslop LA (1993) Product-country Images: Impact and Role in International Marketing. The Haworth Press Inc, New York, USA

18. Insch GS, McBride JB (2004) The impact of country-of-origin cues on consume perceptions of product quality: a binational test of the decomposed country-oforigin construct. Journal of Business Research 57: 256-265.

19. Kabadayi S, Lerman D (2011) Made in China but sold at FAO Schwarz: countryof-origin effect and trusting beliefs. International Marketing Review 28: 102-126.

20. Lantz G, Loeb S (1996) Country of origin and ethnocentrism: an analysis of Canadian and American preferences using social identity theory. Advances in Consumer Research 23: 374-378.

21. Bruning ER (1997) Country of Origin, National Loyalty and Product Choice The Case of International Air Travel. International Marketing Review 14: 59-74.

22. Verlegh P, Steenkamp JB (1999) A review and meta-analysis of country-of origin research. Journalof Economic Psychology 20: 521-546.
23. Peterson RA, Jolibert AJP (1995) A meta-analysis of country-of-origin effects. Journal of International Business Studies 26: 883-900

24. Srikatanyoo N, Gnoth J (2002) Country image and international tertiary education. Journal of Brand Management 10: 139-146.

25. Yasin NM, Noor MN, Mohamad O (2007) Does image of country-of-origin matter to brand equity? Journal of Product \& Brand Management 16: 38-48.

26. Gurhan-Canli Z, Maheswaran D (2000) Cultural Variations in Country of Origin Effects. J Marketing Res 37: 309-317.

27. Khachaturian JL, Morganosky MA (1990) Quality Perceptions by Country of Origin. International Journal of Retail \& Distribution Management 18: 21-30.

28. Ahemd ZU, Astous A (1993) Cross-national Evaluation of Made in Concept Using Multiple Cues. European Journal of Marketing 27: 39-52.

29. Nagashima A (1970) A comparison of Japanese and US attitudes towards foreign products, Journal of Marketing, 34: 67-70.

30. Johansson JK, Douglas SP, Nonaka I (1994) Assessing the impact of country of origin on product evaluations: a new methodological perspective. Journal of Marketing Research 22: 388-396

31. ChinenK, JunM, HamptonGM (2000) Product quality, market presence and buying behaviour: Aggregate images of foreign products in the US Multinational Business Review 8: 29-38.

32. Zain OM and Yasin NM (1997) The importance of country-of-origin information and perceived product quality in Uzbekistan. International Journal of Retail \& Distribution Management 25: 138-145.

33. Pappu R, Quester PG, Cooksey RW (2007) Country Image and ConsumerBased Brand Equity: Relationship and Implications for International Marketing. Journal of International Business Studies, 38: 726-745.

34. Zhou L, Hui KM (2003) Symbolic Value of Foreign Products in the People's Republic of China. Journal of International Marketing 11: 36-58.

35. Cervino J, Sanchez J, Cubillo J (2005) MadeinEffect: Competitive Marketing Strategy and Brand Performance; An Empirical Analysis for Spanish Brands. Journal of American Academy of Business 6: 237-44.

36. Usunier JC (1994) Social status and country-of-origin preferences. Journal of Marketing Management 10: 765-782.

37. Laroche M, Nicolas P, Louise H, Mehdi M (2005) The Influence of Country Image Structure on Consumer Evaluations of Foreign Products. International Marketing Review 22: 96-115.

38. Cordell VV (1992) Effects of Consumer Preferences of Foreign Sourced Products. Journal of International Business Studies 23: 251-269.

39. Elliott GR, Camoron RC (1994)Consumer perception of product quality and the country-of-origin effect. Journal of International Marketing 2: 49-62.

40. Martin IM, Eroglu S (1993) Measuring a Multi-Dimensional Construct: Country Image. J Bus Res 28: 191-210.

41. Dodds WB, Monroe KB, Grewal D (1991) Effects of Price, Brand, and Store Information on Buyer's Product Evaluations. Journal of Marketing Research 28: 307-319.

42. Xianguo Li, Jing Y (2012) The Impact of Country-of-Origin Image,Consumer Ethnocentrism and Animosity on Purchase Intention. Journal of software 7 : 2263-2268.

43. Al-Rajhi, Khalid Sulaiman (2008) The effects of brands and country of origin on consumers' buying intention in Saudi Arabia.

44. DaeHK, Joon HK (2009) Symbolic purchase in sport: The roles of self-image congruence and perceived quality, Manage. Decis 47: 85-99

45. Tsiotsou $R$ (2006) The role of perceived product quality and overall satisfaction on purchase intentions. Int J Consumer Stud 30: 207-217.

46. Richardson PS, Jain AK, Dick A (1996) Household store brand proneness: A framework. J Retail 72: 159-185.

47. Hoch SJ, Banerji S (1993) When do private labels succeed. Sloan Management. Rev 34: 57-67.

48. Ahmed ZU, Johnson JP, Yang X (2004) Does Country of Origin Matter for Lowinvolvement Products. International Marketing Review 21:102-120

49. Han CM, Terpstra V (1988) Country-of-origin effect for uni-national and binational products. Journal of International Business Studies 19: 235-253. 